\title{
Health inequalities among rural and urban population of Eastern Poland in the context of sustainable development
}

\author{
Viktoriya Pantyley ${ }^{1}$ \\ 'School of Socio-Economic Geography Department of Earth Sciences and Spatial Management Maria Curie-Sklodowska
University in Lublin
}

Pantyley V. Health inequalities among rural and urban population of Eastern Poland in the context of sustainable development. Ann Agric Environ Med. 2017; 24(3): 477-483. doi: 10.5604/12321966.1233905

\begin{abstract}
I Abstract
The primary goals of the study were a critical analysis of the concepts associated with health from the perspective of sustainable development, and empirical analysis of health and health- related issues among the rural and urban residents of Eastern Poland in the context of the sustainable development of the region. The study was based on the following research methods: a systemic approach, selection and analysis of the literature and statistical data, developing a special questionnaire concerning socio-economic and health inequalities among the population in the studied area, field research with an interview questionnaire conducted on randomly-selected respondents $(N=1,103)$ in randomly selected areas of the Lubelskie, Podkarpackie, Podlaskie and eastern part of Mazowieckie Provinces (with the division between provincial capital cities - county capital cities - other cities - rural areas). The results of statistical surveys in the studied area with the use of chi-square test and contingence quotients indicated a correlation between the state of health and the following independent variables: age, life quality, social position and financial situation (C-Pearson's coefficient over 0,300 ); a statistically significant yet weak correlation was recorded for gender, household size, place of residence and amount of free time. The conducted analysis proved the existence of a huge gap between state of health of the population in urban and rural areas. In order to eliminate unfavourable differences in the state iof health among the residents of Eastern Poland, and provide equal sustainable development in urban and rural areas of the examined areas, special preventive programmes aimed at the residents of peripheral, marginalized rural areas should be implemented. In these programmes, attention should be paid to preventive measures, early diagnosis of basic civilization and social diseases, and better accessibility to medical services for the residents.
\end{abstract}

\section{Key words}

Eastern Poland, health inequalities, rural population, sustainable development

\section{INTRODUCTION}

Despites the number of initiatives undertaken to improve the health and well-being of society, we continue to face a number of health and socio-economic problems and the polarization of society by increasing health and socioeconomic inequalities at international, national and local levels. The relationship between health and sustainability has been the object of discussion for many years. It has been argued that sustainability is a necessary condition for promoting health and, on the contrary, health must be seen as a precondition for sustainable development [1, 2]. In different international policy documents concerning sustainability, the notion of health is mentioned as a part of social sustainability and one of the basic human needs, among them housing, water supply and sanitation [3, p. 55]. The Adelaide Statement on Health in All Policies emphasises the need for a new social contract between all sectors to achieve human development, equality and sustainability, as well as to improve the health status of the population [4].

In the context of sustainable development, health is often understood as well-having rather than well-being through

Address for correspondente: Viktoriya Pantyley, School of Socio-Economic Geography Department of Earth Sciences and Spatial Management Maria CurieSklodowska University in Lublin

E-mail:vpantyley@gmail.com

Received: 26 May 2016; accepted: 16 January 2017; first published: January 2017 a good standard of life, happiness, the ability to perform everyday activities, and fulfillment of aspirations in life [5]. According to Ríos-Osorio et al. [1, p. 745]: 'health is a harmony of life, a harmony in the chaos that reflects what we are, what we assume as normal and abnormal, the historical being together with a cultural concept which is the product of the historical relation between humans and nature.'

There are a number of works devoted to the impact of socio-economic status on population health $[6,7,8,9,10,11]$, whereas only a relatively small number of works are dedicated to sustainability and health issues $[1,2,12]$. Most of the works concern socio-economic inequalities among different groups of population, and the impact of these inequalities on their state of health. As research conducted in different countries imply, inequality in income levels does not directly affect the deterioration of the health of the population, but contribute to the formation of structural inequalities in access to goods and services. It adversely affects the health of the population through social discrimination, dominant hierarchical structures, inadequate financing of social infrastructure, and the creation of specific risk factors [11, $13,14,15]$. Risk factors include behavioural factors (e.g. smoking, physical activity), cultural factors associated with psychosocial stress, as well as structural factors [16]. At the present time, there are two theories describing the pathways leading to health inequalities: the psychological approach $[6,17]$, according to which social comparisons can increase 
stress levels, and this can be modified by access to social capital, and the materialist approach [18], which claims that income differences at different socio-economic levels are the fundamental mechanism by which inequality is related to the health gradient. Recently, both approaches have contributed to the understanding of how income inequalities may be related to health $[19,20]$.

Health is simultaneously an outcome and precondition of sustainable development and relates to all four pillars of sustainable development: economic, social, environmental and governance. According to the Kickbusch model [21, p. 12], the interaction between the three pillars of sustainable development (economy, society and the environment) is a key determinant for creating healthy and sustainable communities (Fig. 1).

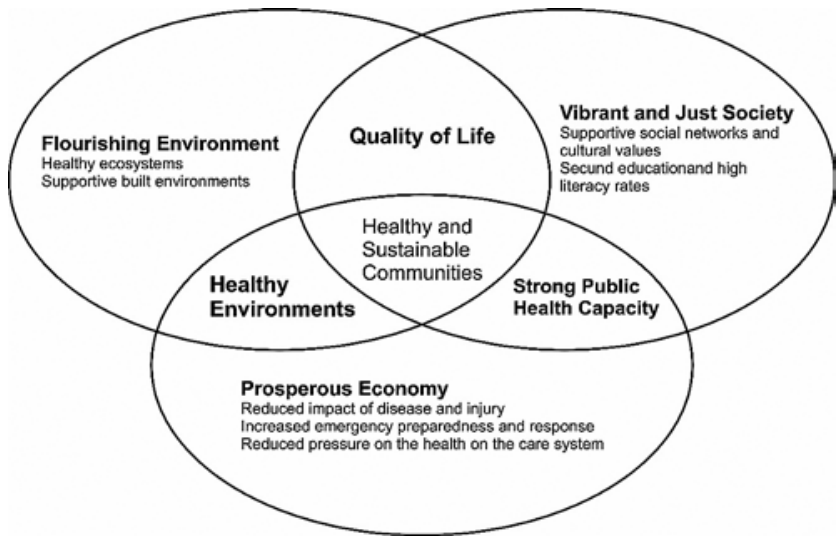

Figure 1. Kickbusch model for public health and sustainable development

It is noted by Kickbusch [21] that there is a convergence in goals and agendas between health promotion and sustainable development. K. B. Pedersen and B. Land [22] use the duality of health and sustainability as a starting point for understanding those two concepts and their mutual relationships. However, both concepts of health and sustainability are mutually enabling and constraining. The concept of duality allows us to understand and develop the integrated strategies, both for health promotion and sustainable development. On the one hand, health creates the necessary condition for the sustainable development of society, while on the other hand, sustainability creates and is conditioned by public health. Consequently, health promotion and prevention must take sustainable development of society.

One of the most important tasks to be undertaken in the public health sector in order to achieve sustainable development of the region, is the reduction in social and health inequalities among the inhabitants of different administrative units at global, regional and local levels. As a research subject, the region of eastern Poland was chosen, one the poorest and most marginalized regions in EU, characterized by low wages, unfavourable income structure and expenses, a significant poverty rate, both extreme and subjective [23]. Such a situation, along with the unfavourable structure of the national economy, high unemployment and large number of 'junk contracts', undoubtedly have negative influence on already existing health inequalities in the region. While analysing the developmental strategies of the provinces of Eastern Poland, one should admit that those strategies are focusing mainly on environmental protection issues, maintenance of biodiversity and monitoring the activities that can contribute to environmental degradation, with no mention of the social and economic pillars of sustainable development, including public health issues $[24,25]$. Therefore, the primary empirical goal of the presented study is analysis of health-related issues among rural and urban residents of Eastern Poland in the context of sustainable development of the region.

\section{MATERIALS AND METHOD}

The spatial extent of the study included 4 administrative units of the highest level in Poland - the entire Lubelskie, Podkarpackie and Podlaskie Provinces, as well as the eastern part of Mazowieckie Province. A special survey was developed on health inequalities and access to medical care of the population in the examined area. The questionnaire consisted of three parts: Part A - containing basic information about the respondents, Part B - containing opinions on the quality of life and health status of the respondents (21 specific questions), Part C - on the level and accessibility to medical services (5 specific questions). The survey was carried out in 2012 on a random sample of respondents in randomly-selected areas of the 4 provinces of Eastern Poland. All the areas were then divided into 4 categories: provincial towns, county cities, other cities, and rural areas. In total, 1,200 surveys were conducted, of which 1,103 fully completed questionnaires were selected for further analysis. The collected data were developed using IBM SPSS Statistics software. Statistical analysis considering qualitative parameters was performed with the application of the chi-square test and C-Pearson contingency coefficients for the determination of correlations between the analysed dependent variables - health condition of the population, and dependent variables, such as age and gender of the population, quality of life, social status, wellbeing, place of residence, household's size, among others.

\section{RESULTS}

Contemporary social and economic changes taking place in the countries of the former so-called 'Eastern bloc' contributed to deepening inequalities in the health status of the population [26]. This was manifested by a deterioration in the quality of life of the population, social gap and different levels of access to goods and services among various socioeconomic groups of the population. This is visible especially in the rural-urban distinction [27].

The health status of the population is usually evaluated by subjective and objective indicators $[28,29]$. In order to investigate the health and socio-economic inequalities among inhabitants of Eastern Poland, field research with an interview questionnaire was conducted among randomlyselected respondents in randomly-selected areas of Lubelskie, Podkarpackie, Podlaskie and eastern part of Mazowieckie Provinces (with the division between provincial capital cities-county capital cities-other cities-rural areas). The characteristics of respondents are given in Table 1.

In order to measure the health status of the population in the examined area, it was decided to use a subjective measure of self-health. Self-assessment of health status of the population is quite often used interchangeably in the literature to objective measures of health status $[14,28,30]$. Respondents were asked to evaluate their health at a given moment. The 
Table 1. Characteristics of surveyed population in Eastern Poland according to administrative units; $\mathrm{N}=1,103$

\begin{tabular}{|c|c|c|c|c|c|c|}
\hline \multirow{2}{*}{$\begin{array}{l}\text { Group } \\
\text { of } \\
\text { features }\end{array}$} & \multirow[b]{2}{*}{ Feature } & \multicolumn{5}{|c|}{ Share of respondents, $\%$} \\
\hline & & $\begin{array}{c}\text { Provincial } \\
\text { capital } \\
\text { cities }\end{array}$ & $\begin{array}{c}\text { County } \\
\text { capital } \\
\text { cities }\end{array}$ & $\begin{array}{l}\text { Other } \\
\text { cities }\end{array}$ & $\begin{array}{l}\text { Rural } \\
\text { areas }\end{array}$ & $\begin{array}{l}\text { Total } \\
\text { areas }\end{array}$ \\
\hline \multirow{2}{*}{ Gender } & female & 76.0 & 64.8 & 76.4 & 73.8 & 71.4 \\
\hline & male & 24.0 & 35.2 & 23.6 & 26.2 & 28.6 \\
\hline \multirow{4}{*}{ Age } & up to 18 years & 0.3 & 2.7 & 0.0 & 4.4 & 2.5 \\
\hline & $18-35$ years & 69.3 & 38.9 & 26.8 & 35.5 & 45.6 \\
\hline & $35-60$ years & 27.4 & 51.7 & 69.6 & 50.4 & 45.5 \\
\hline & above 60 years of age & 3.0 & 6.7 & 3.6 & 9.7 & 6.5 \\
\hline \multirow{3}{*}{$\begin{array}{l}\text { Marital } \\
\text { status }\end{array}$} & unmarried & 47.9 & 29.0 & 14.3 & 29.9 & 33.8 \\
\hline & married & 44.9 & 61.1 & 78.6 & 62.3 & 57.9 \\
\hline & other & 7.3 & 9.9 & 7.1 & 7.8 & 8.3 \\
\hline \multirow{8}{*}{$\begin{array}{l}\text { Employ- } \\
\text { ment } \\
\text { status }\end{array}$} & working in private sector & 48.8 & 27.6 & 29.0 & 19.7 & 31.0 \\
\hline & working in public sector & 15.7 & 36.7 & 48.4 & 19.0 & 25.4 \\
\hline & self-employed & 5.0 & 7.1 & 9.7 & 8.6 & 7.2 \\
\hline & farmer & 0.3 & 0.5 & 0.0 & 15.3 & 5.4 \\
\hline & unemployed & 3.8 & 5.6 & 3.2 & 8.6 & 6.0 \\
\hline & retired & 0.6 & 1.8 & 1.6 & 3.2 & 1.9 \\
\hline & old-age retired & 2.7 & 5.6 & 1.6 & 8.6 & 5.6 \\
\hline & student & 23.1 & 15.2 & 6.5 & 17.0 & 17.6 \\
\hline
\end{tabular}

Source: own elaboration

answers were grouped in 5 categories: very good, good, average, bad, and very bad health. In the light of the selfassessment of health status, $6 \%$ of the population in the area rated their health as poor and very poor. The percentage of people evaluating their health as good or very good was $66.5 \%$. This corresponds with the recent results of CSO selfassessment of health of the Polish population [31]. According to research by the authors of the presented study, the worst situation was observed in the population living in rural areas (8.6\% of respondents rated their health as poor and very poor), and among the population of small and medium-sized cities. In turn, in the area of provincial cities, both the lowest share of people with very bad and poor health (of only $2.7 \%$ ), and highest among other areas studied the participation of people, with a very good and good health $(15.7 \%)$, were recorded (Fig. 2).

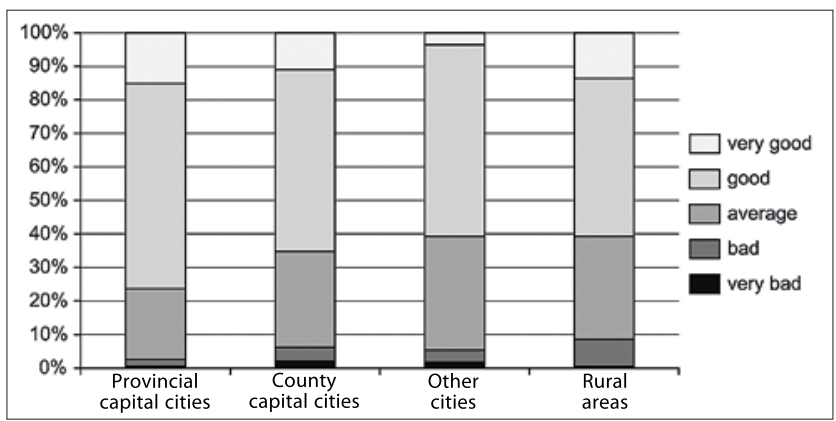

Figure 2. Self-evaluation of health state conditions in respondents from Eastern Poland according to administrative units, $\mathrm{N}=1,103$

For detailed evaluations of the health condition of society, the respondents were asked about social and civilizational diseases within the last 3 years (Tab. 2).
Table 2. Incidence of diseases in respondents from Eastern Poland according to administrative units; $\mathrm{N}=1,103$

\begin{tabular}{lcccc}
\hline \multirow{2}{*}{ Kinds of diseases } & $\begin{array}{c}\text { Provincial } \\
\text { capital cities }\end{array}$ & $\begin{array}{c}\text { County } \\
\text { capital cities }\end{array}$ & $\begin{array}{c}\text { Other } \\
\text { cities }\end{array}$ & $\begin{array}{c}\text { Rural } \\
\text { areas }\end{array}$ \\
\cline { 2 - 5 } & $\begin{array}{c}\text { \% of respondents having particular } \\
\text { diseases within the last 3 } \\
\text { numbers in total }\end{array}$ \\
\hline Allergy & 17.8 & 14.9 & 12.5 & 11.1 \\
\hline Asthma & 4.3 & 4.3 & 0.0 & 3.0 \\
\hline Cardiovascular diseases & 9.9 & 16.8 & 23.2 & 16.6 \\
\hline Digestive diseases & 12.8 & 14.7 & 26.8 & 14.4 \\
\hline Respiratory diseases & 13.5 & 18.7 & 17.9 & 8.3 \\
\hline Diabetes & 2.3 & 2.9 & 0.0 & 3.0 \\
\hline Diseases of musculoskeletal system & 11.2 & 21.1 & 14.3 & 20.2 \\
\hline Thyroid diseases & 7.6 & 5.3 & 8.9 & 5.8 \\
\hline Intensive pain & 27.0 & 20.5 & 14.3 & 21.0 \\
\hline Chronic anxiety & 2.0 & 2.4 & 0.0 & 3.3 \\
\hline Depression & 1.0 & 2.7 & 3.6 & 5.3 \\
\hline Long-lasting injury & 3.6 & 3.5 & 0.0 & 3.6 \\
\hline Cancer & 0.7 & 1.6 & 0.0 & 0.6 \\
\hline Other diseases & 13.2 & 11.7 & 8.9 & 16.3 \\
\hline Source & & & & \\
\hline
\end{tabular}

Source: own elaboration

The results indicate that in the structure of diseases, the dominant conditions included the following: strong pain, experienced by $22 \%$ of respondents, bone and joints diseases $(18 \%)$, cardiovascular and digestive diseases (15\%), respiratory system diseases and allergy (14\%), and thyroid disease (which $6 \%$ of respondents had suffered in the 3 years preceding the survey). Small numbers were recorded for asthma, diabetes, chronic anxiety, depression, and cancer. When it comes to civilization-related diseases, such as allergies, asthma is noted as a characteristic for residents in large cities. It is much more prominent when compared to living in other areas, such as the eastern parts of the Mazowieckie and Lubelskie Provinces. In the case of the incidence of endocrine diseases - diabetes, and thyroid diseases - worse health conditions were characterized in rural areas and small towns. This can be explained by the lower level of health culture and lower attention to preventive measures. There is less accessibility to an endocrinologist in terms of distance and finances. The same is for the incidence of diseases of the osteoarticular system. Diseases of the digestive system, respiratory and cardiovascular systems more often concern the residents of small and medium sized cities. This concerns the provinces in the eastern part of Mazowieckie Province and the whole of the Lubelskie Province. Data on the mental health of the studied population indicate the occurrence of chronic anxiety and depression in the 3 years preceding the survey. The results of research in this area show a clear discrimination of rural areas. This can be related to poverty, especially structural long-term unemployment, the growing tension caused by the lack of psychosocial faith, and hope for the future, which are commonly found in these areas. When it comes to chronic anxiety, the worst situation was recorded for the population of Podkarpacie (the incidence applies to $4 \%$ of respondents), and in the case of depression - the worst situation is in the eastern part of the Mazowieckie Province (almost 6\%).

Examination of the health of the population in Eastern Poland showed a link between state of health and the 
age of the respondents, marital status, education, nature of work and the level of income, but did not show a clear association with gender. Elderly and mature people had the worst opinions about their health condition $(29 \%$ and $5 \%$ of respondents in this age group declared bad health). People with marital statuses other than single and married (almost $10 \%$ of respondents), respondents with incomplete primary education and primary education (23\%), pensioners, oldage pensioners, farmers and the unemployed, people with incomes below or at the social minimum, were also the most vulnerable concerning health self-esteem. The situation of professional groups in this area can be explained by both the poor economic condition of these people, and the low level of health culture. People enjoying good and very good health, according to the results of the presented study, are persons aged $18-35$ years (20\% of respondents), single people (in the case of respondents with very good health), or married people (for those in good health). Also included are respondents with higher and incomplete college degree, students, and people employed in both the public and private sectors, the selfemployed (corresponding shares of respondents fluctuated in the range of $61 \%-48 \%$ for those with good health, and from $19 \%-10 \%$ for those with very good health). People with the highest income (at least $\$ 1,300$ net per person per month in the household) enjoy the best health condition, measured by the highest representation in the income group of people with good and very good health, oscillating around $78 \%$.

The emergence of health inequalities in different socioeconomic groups of the population, as well as between the different categories of settlement units socio-economic inequalities, play an important role. In order to investigate the socio-economic inequalities, the respondents were also asked a series of questions regarding the ability to satisfy basic needs. These needs included: medical needs, model of eating, leisure activities, satisfaction with own quality of life, financial situation, private life, place of residence, employment, housing, social position, and the amount and quality of leisure activities. The results showed that the best financial situation was in the population at working age, the self-employed, and having few offspring. In the group living below the breadline, the unemployed or farmers with many children were the most numerous. In the structure of incomes of the population in the surveyed province, the most dominant were the income from work (about $77 \%$ ), followed by other types of income (e.g., house rental, helping relatives, own savings), and retirement. Approximately $4.5 \%$ of the respondents showed a lack of any income, which may indicate that they are dependent on other people. A particularly high share of people using different types of benefits and other social services in rural areas ( $14 \%$ of respondents) is a disturbing phenomenon. A relatively high proportion of this type of income was declared by city dwellers (approximately 9\%). The respondents were asked about the level of well-being of their households. In the light of relationship between the household's incomes and expenses, studies show that the prevailing households had incomes that were only enough to cover basic needs in food, clothes and dwelling. The largest number of such households were noted in county cities (62.4) and provincial cities (60.5\%). From the spatial aspect, the highest rate of such households was observed in the Podkarpackie Province (63\%). It was especially alarming there was a significant number of households where the income was not sufficient to cover even basic needs. The highest number of such households were noticed in rural areas (27\%) and in small cities (25\%). From the spatial aspect, the highest fraction of such households was in the eastern part of Mazowieckie Province (every $4^{\text {th }}$ respondent) and in Lubelskie Province (every $5^{\text {th }}$ respondent).

An important element in building differences in health status is the level and availability of medical services. The area of Eastern Poland is dominated by a population that uses medical services several times a year (spatial differentiation between the studied areas is 7\%). The smallest group of respondents visited the doctor a few times a month (from $4 \%$ of respondents in the case of small towns to $8 \%$ in rural areas). Comparing the frequency of using medical services, the state of respondents' health and the level of income leads to the conclusion that people in poor and very poor health and with a higher income, use medical services most frequently.

The respondents were also asked about the financial aspect of accessibility to health services. The majority of respondents declared that their level of income was satisfactory only for covering basic needs in health service (broken down by research areas of the differences were only $3 \%$ ). Every $5^{\text {th }}$ respondent declared that the available household's income was not enough, even in the case of medical emergency. It is worrying that there a large share of respondents in rural areas, have with a serious lack of income to make use of health services (up 18\%).This problem particularly affects people with average monthly incomes below the poverty level (27\% of the respondents) and the elderly (23\%). When asked whether in the past year there was a case that the respondents did not use the services of a specialist doctor, despite the real need, almost every $3^{\text {rd }}$ person gave a positive response (Fig. 3 ).

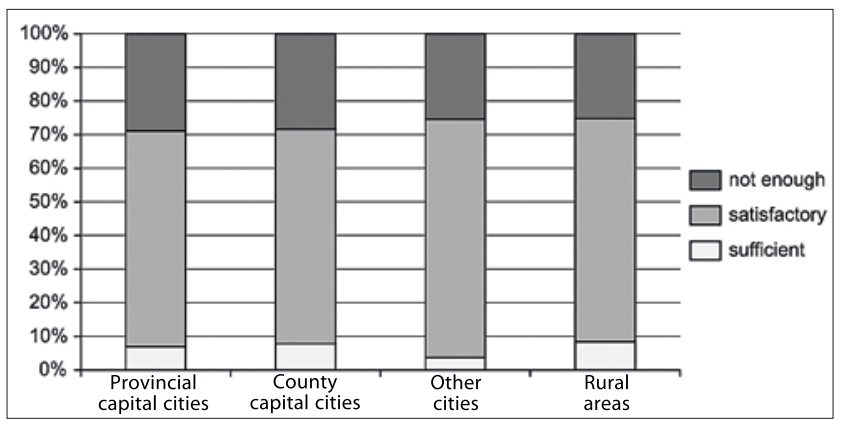

Figure 3. Level of respondents' income vs. access to health service, according to administrative units in Eastern Poland; $\mathrm{N}=1,103$

The population of small towns (32\%) was in the worst situation in this respect. In the structure of the causes of not-using specialist doctor's consultations, the following applies: too long waiting list or no referral from the family doctor (13\%), lack of time (9\%), careless attitude towards health (in this case, the respondents wanted to wait and see if the health problem would rectify itself $-8 \%$ ), and lack of financial resources (8\%). In contrast, the geographical distance factor was not too significant. With regards to only $1 \%$ of the respondents, this was the reason for not using medical services (Tab. 3).

In the case of health problems, the most frequently chosen means of treatment among inhabitants of Eastern Poland were pharmaceuticals ( $76 \%$ of people declared using them), as well as domestic methods (59\%). In the breakdown into research areas, most people with health problems benefited from pharmaceuticals in small towns $(80 \%)$ and provincial 
Table 3. Reasons for not-using medical services by respondents from Eastern Poland according to administrative units; \% of respondents, $\mathrm{N}=1,103$

\begin{tabular}{|c|c|c|c|c|}
\hline \multirow[t]{2}{*}{ Reasons } & $\begin{array}{c}\text { Provincial } \\
\text { capital } \\
\text { cities }\end{array}$ & $\begin{array}{c}\text { County } \\
\text { capital } \\
\text { cities }\end{array}$ & $\begin{array}{l}\text { Other } \\
\text { cities }\end{array}$ & $\begin{array}{l}\text { Rural } \\
\text { areas }\end{array}$ \\
\hline & \multicolumn{4}{|c|}{$\begin{array}{l}\% \text { of respondents in total number of } \\
\text { respondents }\end{array}$} \\
\hline I cannot afford it & 6.6 & 7.2 & 10.7 & 8.6 \\
\hline $\begin{array}{l}\text { Long waiting list, lack of the laboratory } \\
\text { request }\end{array}$ & 12.2 & 14.1 & 8.9 & 12.2 \\
\hline Lack of time & 10.9 & 10.4 & 5.4 & 7.7 \\
\hline Remote location & 0.3 & 0.8 & 0.0 & 2.5 \\
\hline Fear of the doctor/medical procedure & 1.6 & 2.1 & 1.8 & 1.1 \\
\hline I wanted to wait & 8.6 & 6.9 & 14.3 & 8.8 \\
\hline I did not know any good doctor & 3.0 & 3.5 & 3.6 & 0.8 \\
\hline Other reasons & 1.3 & 0.8 & 1.8 & 0.6 \\
\hline
\end{tabular}

Source: own elaboration

cities (77\%). The measures of natural and folk medicine were chosen mostly by residents of provincial cities $(62 \%$ of respondents) and rural areas (59\%). Homeopathic remedies, as studies have shown, were not a popular form of coping with health problems. The juxtaposition of respondents' treatments with such characteristics as gender, education, age and level of income, showed the following regularity: domestic resources as the primary way to deal with health problems (often due to lack of other alternatives), were chosen by those with incomes below the social minimum, people up to 30 years of age, having at most vocational education. Homeopathic remedies, on the contrary, were frequently used by the best-earning population (11.1\% of respondents with incomes above $\$ 1,300$ per person per month), followed by those with a higher or incomplete higher education (5\% of respondents).

In order to determine the relationships between the state of health of the population and selected factors of its development, the chi-square test and C-Pearson coefficient was used. The two-dimensional analysis of the health of the population in the studied area depended moderately on the following variables: age of the population, quality of life, the use of holiday leave, social status, well-being, and financial situation (Tab. 4).

A significant but weak relationship was noted for the following independent variables: gender, marital status, number of children, education level, household size, place of residence, personal life, having friends, housing and employment, and finally, the amount and method of leisure. In any case, there was no statistically strong relationship between the variables and the state of health of the population.

\section{DISCUSSION AND CONCLUSIONS}

The health status of the population is one of the key element of sustainable development of the country and its regions, and, simultaneously, it is a crucial factor for sustainable development. The strategy of sustainable development of Eastern Poland should take into consideration sustainability from the health perspective and health in sustainability perspective, and address both perspectives in the development strategies of the examined provinces. Analysis of these strategies for the provinces in Eastern Poland to the year 2020 showed that health related problems, on the contrary to ecological and economic problems, were underestimated $[24,25]$. Conducted analysis proved the existence of a huge gap between health state of the population in urban and rural areas of Eastern Poland, similar to the research of other authors concerning different regions of Poland [32, 33, 34]. The results of the survey among the inhabitants of Eastern Poland with use of the chi-square test and contingency coefficients revealed a moderate relationship between the state of health of the population and the following independent variables: age, quality of life, social status and financial situation (C-Pearson contingency coefficient over 0,300 ). A significant relationship, but to a small extent, was recorded in the case of gender, marital status, the number of children, education level, household size, place of residence, personal life, having friends, housing conditions, work situation, leisure activities and their quantity. In any case, there was no statistically strong relationship between the variables, and the state of health of the population.

The results of the presented study concerning Eastern Poland generally correspond to the results of studies from other countries (Norway, Hungary, South Africa, USA and Netherlands), and indicate a relationship between the socioeconomic position, and self-assessment of health status [35, $36,37,38,39,7]$. Research conducted by K. M. Olsen and S. A. Dahl [13] concerning the differences in the health of residents of 21 European countries showed that the health status of the population in the analysed countries depended on a variety of political, socio-economic and behavioural characteristics.

Table 4. Relationship between health state and selected statistically important variables in the research area

\begin{tabular}{|c|c|c|c|c|c|c|}
\hline & $\begin{array}{l}\text { Empirical number } \\
\text { of the statistics }\end{array}$ & Degree of freedom & $\begin{array}{l}\text { Statistical } \\
\text { significance }\end{array}$ & Critical value & $\begin{array}{l}\text { Test probability ( } p \\
\text { level for the test) }\end{array}$ & $\begin{array}{l}\text { Pearson's } \\
\text { C-indicator }\end{array}$ \\
\hline $\begin{array}{l}\text { Dependent: health state of population; } \\
\text { independent: age }\end{array}$ & 112,562 & 3 & 0.05 & 7,815 & 0,0001 & 0,305 \\
\hline $\begin{array}{l}\text { Dependent: health state of population; } \\
\text { independent: life quality }\end{array}$ & 252,388 & 9 & 0.05 & 16,919 & 0,0001 & 0,423 \\
\hline $\begin{array}{l}\text { Dependent: health state of population; } \\
\text { independent: social status }\end{array}$ & 135,903 & 9 & 0.05 & 16,919 & 0,0001 & 0,335 \\
\hline $\begin{array}{l}\text { Dependent: health state of population; } \\
\text { independent: financial situation }\end{array}$ & 122,265 & 9 & 0.05 & 16,919 & 0,0001 & 0,317 \\
\hline $\begin{array}{l}\text { Dependent: health state of population; } \\
\text { independent: Rusing holidays }\end{array}$ & 121,424 & 9 & 0.05 & 16,919 & 0,0001 & 0,316 \\
\hline
\end{tabular}

Source: own elaboration 
However, these studies showed that individual measures of satisfaction with the level of income and social capital have a stronger relationship with self-evaluation of health status than with socio-economic measures. The study of differences in health between European countries proved that in all of the analysed European countries, including Poland, selfassessment of health increases with income. This is similar to the studies of L. S. Wolff et al. [38] concerning the USA. According to these studies, self-rated health was dependent on household income, education, home ownership, and race/ethnicity. Additionally, studies conducted by R. Ram in the USA [39] showed a strong association between income inequality and mortality, as well as the healthy of the population. E. Nolte and M. McKee [40] proved that education and income level in eastern and western parts of Germany were important determinants of health for both parts of the country. This thesis is partly confirmed by the current study (in terms of income level) in relation to Eastern Poland, which is characterized by considerable social fragmentation and the existence of large disparities in terms of socio-economic status of the population on the line between a provincial settlement, and show a considerable advantage in rural areas. It turned out that in rural areas it is the financial factor, rather than the distance to medical centres that is the key factor in the availability of medical assistance. Financial factors also affect respondents' choices of treatment in the event of health problems. The level of education and professional status of the population in Eastern Poland, as in studies by other authors [14, 38, 40], did not play such a significant role in the differentiation of the level of health of the population, as the income level and age. K. Stronks et al. proved that the low income in The Netherlands had definite health effects through relative deprivation; there was an indirect link between deprivation and health problems involving psychological and behavioural factors [7]. Unfortunately, these factors were not taken into consideration the presented study.

Mitigating the inequalities in the health status of Eastern Poland residents is an important priority in the context of sustainable development for both Poland and the EU. In order to eliminate differences, actions should be taken to improve the situation. First of all, specific prevention programmes should implement, targeted to marginalized residents of depressed rural areas, focused on prevention and early detection of primary civilization and social diseases, and improving the financial access to medical services for the population in the region.

\section{Acknowledgements}

The study was a part of the National Science Centre Project No. NN 306700940, 'The influence of socio-economic transformations on the demographic potential in Eastern Poland - diagnosis and predictions'.

\section{RERERENCES}

1. Ríos-Osorio LA, Salas-Zapata WA, Ortiz-Lobato M. Concepts Associated with Health from the Perspective of Sustainable Development. Saúde e Sociedade, Sâo Paulo. 2012; 21(3): 735-746.

2. Kjærgård B, Land B, Pedersen KB. Health and sustainability. Health Promot. Int. 2014; 29(3): 558-568.

3. WCED. Our Common Future. World Commission on Environment and Development, Oxford University Press, 1987.
4. The Adelaide Statement on Health in All Policies: moving towards a shared governance for health and well-being. WHO and the Government of South Australia. Health Promotion International 2010; 25(2): 258-260.

5. Latouche S. Standard of living. In: Sachs W, editor. The development dictionary. A guide to knowledge as power. Zed Books, London-New York; 2010, p. 279-94.

6. Wilkinson RG. Unhealthy societies: The afflictions of inequality. Routledge, London,1996.

7. Stronks K, van de Mheen HD, Mackenbach JP. A higher prevalence of health problems in low income groups: does it reflect relative deprivation? J Epidemiol Community Health. 1998; 52(2): 548-57.

8. Asthana S, Gibson A, Moon G, Brigham P, Dicker J. The demographic and social class basis of the inequality in self-reported morbidity: an exploration using the Health Survey for England. J Epidemiol Community Health. 2004; 58: 303-307.

9. Ram R., 2006, Further examination of the cross-country association between income inequality and population health. Soc Sci Med. 2006; 62(3): 779-91.

10. Wilkinson RG, Pickett KE. Income inequality and population health: A review and explanation of the evidence. Soc Sci Med. 2006; 62: 1768-84.

11. Nobles J, Ritterman Weintraub M, Adler NE, Subjective socioeconomic status and health: Relationships reconsidered. Soc Sci Med. 2013; 82: 58-66.

12. Health in the framework of sustainable development. Technical Report for the Post-2015 Development Agenda, 2014. Sustainable Development Solutions Network, A Global Initiative for the United Nations http:// www.unsdsn.org (access: 2016.03.30).

13. Olsen KM, Dahl SA. Health differences between European countries. Soc Sci Med. 2007; 64(8): 1665-78.

14. Mansyur C, Amick BC, Harrist RB, Franzini L. Social capital, income inequality and self-related health in 45 countries. Soc Sci Med. 2008; 66(1): 43-56.

15. Semyonov M, Lewin-Epstein N., Maskileyson D. Where wealth matter more for health: The wealth-health gradient in 16 countries. Soc Sci Med. 2013; 81: 10-17.

16. Davey-Smith G, Bartley M, Blane D. Explanations for socioeconomic differentials in mortality: evidence from Britain and elsewhere. Eur J Public Health. 1994; 4: 131-44.

17. Kawachi I, Berkman LF. Social cohesion, social capital, and health. In: Berkman LF, Kawachi I, editors. Social Epidemiology. Oxford University Press, New York; 2000, p. 184-190.

18. Lynch JW, Kaplan GA. Socioeconomic position. In: Berkman LF, Kawachi I, editors. Social Epidemiology. Oxford University Press, New York; 2000, p. 13-35.

19. Szreter S, Woolcock M. Health by association? Social capital, social theory, and the political economy of public health. Int J Epidemiol. 2004; 33(4): 650-67.

20. Schnittker J, McLeod JD. The social psychology of health disparities. Annu Rev Sociol. 2005; 31: 75-103.

21. Kickbusch I. Triggering debate, White Paper: The Food System - a prism of present and future challenges for health promotion and sustainable development. Health Promotion, Switzerland, 2010. http://www.scpknowledge.eu/sites/default/files/knowledge/attachments/WhitePaper. KickbuschIlona.HPS_.pdf (access: 2016.03.25).

22. Pedersen KB, Land B. Health, Food and Sustainability. In: Nielsen KA, Elling B, Figueroa M, and Jelsøe E, editors. A New Agenda for Sustainability. Ashgate, United Kingdom; 2010, p. 251-269.

23. Bański J, Pantyley V, Janicki W, Flaga M, Wesołowska M. Współczesne przekształcenia społeczno-gospodarcze a potencjał ludnościowy wschodniej Polski. Studia Obszarów Wiejskich, 36, PTG, IGiPZ PAN, Warszawa, 2014.

24. Makarewicz-Marcinkiewicz A. Holistyczna koncepcja zrównoważonego rozwoju w strategiach polskich województw do roku 2020. Problemy ekorozwoju/Problems of Sustainable Development. 2015; 4(2): 103-113.

25. Widomski MK, Gleń P, Łagód G, Jaromin-Gleń M. Rozwój zrównoważony jednego z najbiedniejszych regionów Unii Europejskiej, Województwa Lubelskiego - próba oceny. Problemy ekorozwoju/ Problems of Sustainable Development. 2015; 10(2): 137-149.

26. Social Inequalities in Health on Poland. 2012. WHO, Regional Office for Europe.

27. Laskowska I. Availability of health services vs. health condition of residents of rural areas in Poland - Analysis performed on the basis of EHIS 2009. Ann Agric Environ Med. 2015; 22(4): 700-703.

28. Frankenberg E, Jones NR. Self-rated health and mortality: does the relationship extend to a low income setting? J Health Soc Behav. 2004; 45(4): 441-52. 
29. Poortinga W. Social capital: An individual or collective resource for health. Soc Sci Med. 2006; 62: 292-302.

30. Jylhä M, Volpato S, Guralnik JM. Self-rated health showed a graded association with frequently used biomarkers in a large population sample. J Clin Epidemiol. 2008; 59: 465-471.

31. Stan zdrowia ludności Polski w 2014 r. 2016. GUS, Warszawa

32. Krzyżak M. Maślach D, Szpak A, Piotrowska K, Florczyk K, Skrodzka M, Owoc A, Bojar I. Trends of potential years of life lost due to main causes of deaths in urban and rural population in Poland, 2002-2011. Ann Agric Environ Med. 2015; 22(3): 564-571.

33. Maniecka-Bryła I, Pikala M, Bryła M. Health inequalities among rural and urban inhabitants of Łódz Province, Poland. Ann Agric Environ Med. 2010; 19(4): 723-31.

34. Lipowicz A. Disparities in health status between rural and urban adult males in Lower Silesia, Poland. Anthropol Anz. 2015; 72(1): 13-25.
35. Friestad C, Klepp KI. Socioeconomic status and health behavior patterns through adolescence. Eur J Public Health. 2006; 16(1): 41-47.

36. Kopp M, Skrabski A, Réthelyi J, Kawachi I, Adler NE. Self-rated health, subjective social status, and middle-aged mortality in a changing society. Behav Med. 2004; 30(2): 65-70.

37. Hamad R, Fernald LCH, Karlan DS, Zinman J. Social and economic correlates of depressive symptoms and perceived stress in South African adults. J Epidemiol Community Health. 2008; 62: 538-44.

38. Wolff LS, Subramanian SV, Acevedo-Garcia D, Weber D, Kawachi I. Compared to whom? Subjective social status, self-rated health, and referent group sensitivity in a diverse US sample. Soc Sci Med. 2010; 70: 2019-2028.

39. Ram R. Income inequality, poverty, and population health: Evidence from recent data for the United States. Soc Sci Med. 2005; 61: 2568-2576.

40. Nolte E, McKee M. Changing health inequalities in east and west Germany since unification. Soc Sci Med. 2004; 58: 119-136. 